\title{
Need Analysis of Developing English Module Through Poster Presentation Assisted by Vlog
}

\author{
Rasmita $^{1}$ and Shally Amna ${ }^{2}$ \\ ${ }^{1}$ Universitas Putra Indonesia YPTK, Padang, Indonesia, $\triangle$ (email), mi2t.caem85@gmail.com \\ ${ }^{2}$-Universitas Putra Indonesia YPTK, Padang, Indonesia, $\triangle$ (email), shallyamna@upiyptk.ac.id
}

\begin{abstract}
The research aims to analyze the need for English module and learning strategy for students in Information System department of Computer Science Faculty UPI-YPTK Padang. The method used was a descriptiveanalytic and qualitative approach to describe the students' needs. The data were collected through interview and questionnaires. The research applied Need Analysis (NA) theory of Dudley-Evan and St. John (1998). There were four lecturers and one hundred fifty students in the 2017/2018 academic years participated and chosen by purposive random sampling. The results of this study indicated that there was urgency of an English module for students from Information System department. It should contain more grammar and speaking activities, groups work and out-of-classes activities. This research will also be used as guidance to develop a module and further studies.
\end{abstract}

\section{Keywords: Need Analysis (NA), Module, Learning Strategy}

\section{INTRODUCTION}

English is a very important international language which connects someone to the world in various aspects such as education, business, economics, and works. In the field of education, government regulations has set English language course as a compulsory subject to be learnt from low to high education. In university, all study programs enroll English language courses for one or two semesters, although the majors taken are non-English. Learning English in higher education is not just about giving material, topics, methods and strategies, but also learning experiences that enable students to learn independently. One of the supporting factors is the availability of adequate resources such as the availability of textbooks or teaching materials.

However, Information System department of computer science faculty at UPI YPTK Padang, the learning process of English courses in the class were still relatively conservative. Almost all of the lectures still use teacher-centered method and limited media used such as old textbooks, blackboard and power point. In the teaching and learning process, students only listen to the the lecturer, re-copy what the lecturers explain, and do the tasks. At the end of the semester, the English grade rate obtained is commonly not satisfying. It is approximately $40 \%$ of all the students earn satisfactory grade in English courses.

Furthermore, the evaluation regards to poor learning outcomes has revealed several facts of causes. Those are; (1) the number of hours for English language lessons is not adequate to present a comprehensive theory, (2) the number of students in the class that does not allow them for having individual practice, (3) the weakness of students' confidence in practicing English, and (4) the lack of interest and motivation in learning English because of the monotonous learning process. To overcome problems, it is necessary to change the pattern of learning approaches from teacher-centered method to become a student-centred method in order to make students become more active. It is also noteworthy to provide students with appropriate teaching materials which are suitable from non-English department. Therefore, this research is aimed to analyze the students need on a new module with students-centered method in Information System department of Computer Science Faculty, UPI YPTK Padang, Indonesia.

Module is programmed learning materials which are arranged in such a way and that are presented in a systematic, detailed and integrated manner (Daryanto, 2013). In addition, according to Asyhar (2012), the module as one form of printed teaching material is designed for self-study equipped with self-study instructions. Susilana and Riyana (2009) also mentions that the module is a program package that is compiled and designed for students' learning interests. By having a module, students can keep up easily. Moreover, the students' experience can be used as an approach to module learning. An educator can motivate students in learning so that they can get involved actively during the learning process.

From the explanation above, it can be concluded that the module is a tool or mean of learning containing certain material aimed at students being able to learn independently, and ways to evaluate those designed systematically, and interesting to achieve the learning goals. Furthermore, as the comparison of this research, 
there are some previous studies in need analysis (NA) has been done by many researchers. Diana, S. and Mansur, M (2018) did need analysis research on English teaching materials for ICT students. They found that the English materials needed for the students of genetic computer school Singapore in learning English. They used qualitative and quantitative methods in collecting the data and They also interviewed the lecturers and gave questionnaires for students in the 2017/2018 academic years chosen by purposive sampling. The result of the research was new English teaching materials focusing on speaking and writing skill developed specifically for ICT students. Then, Wisma Yunita, E, and Muyani, I. (2018) with title "Need analysis for English grammar learning model from students'perspectives". The research was to find the need for learning English grammar from students' perspectives at the ESP of the University of Bengkulu. The data using a questionnaire with 65 questions given to 44 students who took Structure-1 course in the 2016/2017 academic year and They analyzed it quantitatively. They found that the students need clear goal of learning English grammar, learning approaches that use the story-based, the deductive, and the inductive approach. Next, Marjan, M. (2014) investigated the perceived English language needs of students in the General Course for all non-English major at Iran University. The result of the study is perceived reading as the most important skill, besides listening and speaking as the most problematic skill for students in Iran.

Therefore, the finding of the previous research studies here are highly relevant to this research idea. Firstly, to investigate the English language needs of students about the General English (GE) course in the Information System department of Computer Science Faculty at UPI-YPTK Padang. Secondly, this research also uses qualitative and quantitative method in collecting data. Thirdly, the researchers plan to develop an English module for students non-English majors. Moreover, need analysis is one of the most important steps to develop a module in English for non-English department students. Many experts from previous researches have suggested the theory proposed by Hutchinson and Waters (1987). They stated that there are two things to be analyzed; (1) target needs, it is what the students' need, lack and wants. (2) learning needs; what the students need to be learned. Richard (2001) mentions the profile of communicative need which is personal, medium, purpose, target level, interactional variable, etc. Then, Dudley-Evans St.John (1998) suggested eight aspects for analyzing students needs; (1) wants, means, subjective needs analysis. (2) present situation analysis. (3) target situation analysis and objective need. (4) lack analysis. (5) learning needs analysis. (6) linguistic analysis. (7) what is wanted from the course, and (8) the last analysis is means analysis.

\section{METHOD}

This research is done by using a qualitative descriptive approach. The data of the research are divided into three categories. The first data are obtained by giving the questionnaire to 150 system information students who have studied the English language in the first semester. The questionnaire is designed by adapting the concept of Dudley-Evans and Jo St. John (1998) which are categorized into wants, present situation analysis, target situation, and objective analysis, lacks analysis, learning needs, linguistics, discourse, and genre analysis, what is wanted from the course and means analysis. The questionnaire given is written in the Indonesian language to give more comprehension toward the questions. The second data of the research is obtained by interviewing all of the lecturers who teach English in the system information department. The interviewed is done directly by asking several issues related to the need for a module in teaching the English language in the first semester in the system information department. The third data come from the result of the students' previous grades. The third data are used only as a comparison to the result of the questionnaire.

The first data are analyzed quantitatively by using descriptive statistics to describe the frequency and the percentage of the students' answers in the questionnaire. The formula addapted from Arikunto (2006) used as follow:

$$
\begin{aligned}
& \mathrm{P}=\mathrm{f} / \mathrm{N} \times 100 \\
& \text { (1) } \\
& \text { Notes: } \\
& \mathrm{P}=\text { percentage, } \\
& \mathrm{f}=\text { answering frequency } \\
& \mathrm{N}=\text { the number of respondents }
\end{aligned}
$$

The result of the questionnaire will be presented qualitatively and quantitatively. The result of the second and third data is explained descriptively. Furthermore, all of the data will be compared to conclude the main need for the English language module of system information students. The object of this research is 150 system information students and English lecturers in computer science faculty UPI-YPTK Padang. The students are now in the second semester/the first-year academic. These students have already learned the English language in the first semester.

\section{RESULT AND DISCUSSION}

In conducting the researching of need analysis, there are some aspects below:

1. Questionnaires analysis

A. Wants, means, subjective needs analysis.

The questions in this category look for students' perceptions of learning English, how often they deal with English activities outside the English class, and what they prefer to study in the first semester. The first answers' choices are ranked from very important, important, less important, and unimportant. The second was ranked from 'always', 'often', 'seldom', and 'never'. The third choice was ranked between 'yes' and 'no'. 
Table 1. Wants, means, subjective needs analysis

\begin{tabular}{llrcc}
\hline No & \multicolumn{1}{c}{ Questions } & Answer & $\%$ \\
\hline A1 & $\begin{array}{l}\text { As the first year system } \\
\text { information student, how } \\
\text { important } \\
\text { proficiency? }\end{array}$ & $\begin{array}{c}\text { Very } \\
\text { importa }\end{array}$ & $76.7 \%$ \\
A2 & $\begin{array}{l}\text { To improve your English } \\
\text { proficiency, how often do you } \\
\text { do activities using English out } \\
\text { of your English class? }\end{array}$ & Seldom & $52.7 \%$ \\
\hline A3 & $\begin{array}{l}\text { To learn the English language } \\
\text { in the first semester, do you } \\
\text { prefer to learn general English } \\
\text { or English for Specific } \\
\text { Purposes? }\end{array}$ & English & \\
\end{tabular}

Based on table 3.1, data showed that first-year students in the system information department of computer science faculty at UPI YPTK Padang argue that English is a very important skill, this is evidenced by the data obtained from the questionnaire of 76.7 percent. Unfortunately, they rarely use English outside the classroom, this is evidenced by only 52.7 percent of the total respondents. From this data, it was also obtained 73.3 percent of students answered that they were more grateful to learn general English than special English (English for Specific Purposes / ESP).

\section{B. Present Situation Analysis}

Students who answer the questions in this questionnaire have learned General English (GE) course in the first semester. Therefore, it is important to ask their opinion about the present situation of learning English related to the textbook they used before. The answers' choices are rank between 'yes' and 'no'. Here are the results of the questionnaires:

Table 2. Present situation analysis

\begin{tabular}{|c|c|c|c|}
\hline No & Questions & Answer & $\%$ \\
\hline B1 & $\begin{array}{l}\text { Was the textbook you used in } \\
\text { learning English was the first } \\
\text { publishing and was not up to date? }\end{array}$ & Yes & 77.3 \\
\hline B2 & $\begin{array}{l}\text { Was the textbook you used in } \\
\text { learning English easy to be } \\
\text { comprehended? }\end{array}$ & No & 53.3 \\
\hline B3 & $\begin{array}{l}\text { Can the textbook you used in } \\
\text { learning English be used as a self- } \\
\text { study? }\end{array}$ & No & 58.7 \\
\hline
\end{tabular}

In B1 questions form the table above, $77.3 \%$ of students answer 'no' because, it is in fact, the module they used in learning English in last semester was Cutting Edge by Sarah Cunningham and Peter Moor in 1998. The book was meant to be used as English as a second language. However, in Indonesia, especially for most of the students who learned English in the information system at UPI YPTK Padang, English is still a foreign language.
Therefore, the Cutting Edge book was difficult to be comprehended. In other words, most students cannot use the book only by themselves without the lecturer's guidance. In B2 questions, most of the students argued that the textbook books they had learned could not be understood, this was taken from the questionnaire data given to them and their responses were no more than 53.3 percent. Also, the textbook does not help them to learn more independently on their own, this is evidenced by their answers in B3 questions with a response rate of 58,7 percent.

Based on the data analysis above the researchers can be concluded that the first-year academic students in information systems at UPI YPTK Padang, need something new for learning English courses. That is in the form of textbooks or modules that can help them learn more independently on their own.

\section{Target Situation and Adjective Needs.}

The questions in this category are divided into two tables. The questions 7 to 9 ask about the benefit of learning English based on the students' point of view. The questions 10 to 14 ask about how important learning English skills: speaking, grammar, listening, reading, and writing. All of the answers' choices are ranked from very important, important, less important, and unimportant

Table. 3 Target situation and adjective needs

\begin{tabular}{llcc}
\hline No & \multicolumn{1}{c}{ Questions } & Answer & $\%$ \\
\hline C7 & $\begin{array}{l}\text { To review English language } \\
\text { as general }\end{array}$ & Important & 54.0 \\
\hline C8 & $\begin{array}{l}\text { To equalize students' basic } \\
\text { English before learning ESP } \\
\text { in the second semester. }\end{array}$ & Important & 58.7 \\
C9 & $\begin{array}{l}\text { To learn English at a higher } \\
\text { level }\end{array}$ & $\begin{array}{c}\text { Very } \\
\text { Important }\end{array}$ & 54.0 \\
\hline C10 & To learn Speaking & Very & 60.7 \\
& & Important & \\
\hline C11 & To learn Grammar & Very & 61.3 \\
& & Important & \\
\hline C12 & To learn Listening & Very & 55.3 \\
& & Important & \\
\hline C13 & To learn Reading & Important & 50.7 \\
\hline C14 & To learn Writing & Very & 52.7 \\
& & Important & \\
\hline
\end{tabular}

Based on Table 3, C7 until C9 explains the important English language functions taught to review in general English and learn English at a higher level. Besides, the students prefer to study English 1 as basic English before studying ESP (English for Specific Purposes) in the next semester. Then, C10 until C14 describes that speaking and grammar as English skills with data of 60.7 percent and 61.3 percent, which must be learned by students in the first year of learning English in the college. 
D. Lack of Analysis

Table 4. Lack analysis

\begin{tabular}{cllc}
\hline No & Questions & Answer & $\%$ \\
\hline D15 & Speaking & Less & 61.3 \\
\hline D16 & Grammar & Less & 64.7 \\
\hline D17 & Listening & Less & 51.3 \\
\hline D18 & Reading & Good & 62.7 \\
\hline D19 & Writing & Good & 62.7
\end{tabular}

Based on table 3.4 above, the data obtained from the questionnaire questions shows that the English language skills of all respondents are spoken with data obtained is 61,3 percent and grammar is 64,7 percent, while listening is the lowest ability of students at 51,3 percent. This is caused by their lack of using English in their daily life and they rarely listen to music lyrics in the western genre.

\section{E.Learning Need Analysis}

Based on the questionnaire, it can be said that English components of grammar and speaking 52.0 and 50.7 percent that they need to study in English course in the first semester, can be seen in the table 3.5. In additional, group activities are very important for first students at UPI YPTK Padang, this is provided with questionnaire results $56.0 \%$ of all respondents' responses.

Table 5. Learning need analysis

\begin{tabular}{|c|c|c|c|}
\hline No & Questions & Answer & $\%$ \\
\hline E20a & Listening & $\begin{array}{c}\text { Very } \\
\text { Important }\end{array}$ & 40.0 \\
\hline E20b & Speaking & $\begin{array}{c}\text { Very } \\
\text { Important }\end{array}$ & 50.7 \\
\hline E20c & Reading & $\begin{array}{c}\text { Very } \\
\text { Important }\end{array}$ & 36.7 \\
\hline E20d & Writing & Important & 36.0 \\
\hline E20f & Grammar & $\begin{array}{c}\text { Very } \\
\text { Important }\end{array}$ & 52.0 \\
\hline E21a & Pair work & Important & 31.3 \\
\hline $\mathrm{E} 21 \mathrm{~b}$ & Whole class activity & $\begin{array}{c}\text { Very } \\
\text { Important }\end{array}$ & 33.3 \\
\hline E21c & Group work & $\begin{array}{c}\text { Very } \\
\text { Important }\end{array}$ & 56.0 \\
\hline E21d & $\begin{array}{l}\text { Outside } \\
\text { activity }\end{array}$ & Important & 50.7 \\
\hline E21f & Individual work & $\begin{array}{c}\text { Very } \\
\text { Important }\end{array}$ & 38.7 \\
\hline
\end{tabular}

F. Linguistics Analysis

Table 6. Linguistic analysis

\begin{tabular}{|c|c|c|c|}
\hline No & Questions & Answer & $\%$ \\
\hline F22 & $\begin{array}{l}\text { Language Approach in } \\
\text { used in a textbook }\end{array}$ & $\begin{array}{c}\text { Mix (Indonesian - } \\
\text { English) }\end{array}$ & 56.0 \\
\hline F23 & $\begin{array}{l}\text { What topics do you want } \\
\text { to learn in English class? }\end{array}$ & $\begin{array}{l}\text { Introduction } \\
\text { Part of Speech } \\
\text { Daily Activities } \\
\text { Describing People } \\
\text { and Place } \\
\text { Past Experience } \\
\text { Achievement } \\
\text { Etc. }\end{array}$ & \\
\hline
\end{tabular}

From the table F. 22 above, it can be seen that the respondents wanted to mix the Indonesian language with English in the choice of language to be used in the English learning module with $56,0 \%$ of all students. Respondents argue that the existence of these two languages (Indonesian and English) they can better understand the subject matter because in general, not all students in the first year are proficient in English, moreover English is their second language. Next, from the table F. 23, it is shown that there is some number of topics that students want to learn in the first year in English courses, namely introduction, part of speech, daily activities, describing people, past experience, achievement, etc. With the reason that these topics are the basic things, they can use when communicating with each other every day.

G. The analysis of what is wanted from the course.

Table 7. The analysis of what is wanted form the course

\begin{tabular}{clll}
\hline No & \multicolumn{1}{c}{ Questions } & Answer & $\%$ \\
\hline G24 & $\begin{array}{l}\text { What do you expect to get } \\
\text { after learning English } \\
\text { language in the first semester? }\end{array}$ & $\begin{array}{l}\text { To improve } \\
\text { English as } \\
\text { general }\end{array}$ & \\
& &
\end{tabular}

Based on table 3.7 above, it is shown that $88,7 \%$ of students expect to improve their English as general in the first semester. For several reasons, among others, because English is a universal language as the language most widely used by people on this earth so that it can be easy in communicating with various people of the world, they also find it cooler to insert a few English words in a daily chat with their friends.

\section{H. Means Analysis}

The following table obtained data about 76.0 percent of respondents, they wanted a mixture of teacher center methods with students center in the teaching and learning process. The respondents argued that because they were first-year students studying in college, so they still needed a mix of Indonesian and English language in their English course learning modules later. 
Table 8 Means analysis

\begin{tabular}{clll}
\hline No & \multicolumn{1}{c}{ Questions } & \multicolumn{1}{c}{ Answer } & \% \\
\hline H25 & $\begin{array}{l}\text { What methods of } \\
\text { learning English do } \\
\text { you want? }\end{array}$ & $\begin{array}{l}\text { Mix (Student- } \\
\text { Teacher center) }\end{array}$ & 76.0 \\
& & \\
\end{tabular}

\section{Interview Analysis}

Based on the results of the interview analysis with lecturers who teach English courses in the information system department at UPI YPTK Padang, there were four lectures which were used as respondents in this research. It can be concluded that the lecturers stated that currently there is no English language module, they only use a textbook titled Cutting Edge in the teaching and learning process. The textbook has several disadvantages, among others; the first is that the book is still an old edition (1998), the second difficulty level is too high and complicated, the third cannot be used as a selfstudy material for students in the first year of college, and the language in a less interactive book.

\section{Previous Test Analysis}

Based on the results of interviews with the lecturers who teach English courses in the information system department at the computer science faculty to study, it can be concluded that most students in the first semester scored below average or low for graduation rates in English courses. In addition, based on the experience of researchers who also teach English language courses, from six classes taught in English only 10 percent of students get satisfactory grades or rank A, while 30 percent of them get rank $\mathrm{B}$, and the remaining 70 percent generally get students rank $\mathrm{C}$ or $\mathrm{D}$.

\section{CONCLUSION}

Before starting research on module development, need analysis is the first step to find out the situations and conditions that occur in the field, responses or opinions of students to the English courses that they have been studied, students' test results in English subjects and lecturers' perceptions of textbooks or modules that have been used. Based on all of the data need analysis, it can be concluded that the students at information systems department required a module in learning English 1, which the material consists of the general English, it can be used as an introduction to basic English for learning ESP (English for Specific Purposes) in the next semester.

The important of materials that must be learned in the English module 1 is material related to grammar and speaking skills. This is evidenced from the data need analysis which states that generally grammar and speaking are the lowest ability of respondents. In additional, the learning method desired by the respondents is group learning and activities outside class activity.

Furthermore, the language of instruction used in the module is Indonesian and English. Therefore, the researchers need to continue this research for developing the module stage in learning English through poster presentation and vlog, with reasons through poster presentation where students can work in groups and by using vlogs that students can do projects outside the classroom to make short conversations by using English.

\section{ACKNOWLEDGMENTS}

The authors would also like to Dr. Muharika Dewi for the reviews.

\section{REFERENCES}

[1] Arikunto, Suharsimi. 2006. Prosedur Penelitian: Suatu Pendekatan Praktek. Jakarta: PT Rineka Cipta.

[2] Bryant, T. (2006). Using World of Warcraft and other MMORPGs to poster a targeted, social and cooperative approach toward language learning. Available at: htmp//www.academiccommons.org/commons/essa y/ Bryant-MMORPGs-for SLA,

[3] Daryanto. (2013). Media Visual Untuk Pengajaran Teknik. Bandung: Tarsinto.

[4] Diana, S., and Mansur. (2018). Need Analysis on English Teaching Materials for ICT Students. Jurnal uin-alauddin.ac.id Vol. 4(2). 209-218

[5] Dudley-Evans, T., and M.C.s. John. (1998) .Development in English for Specific Purposes: A Multidaysculinary Approach. Cambridge: CUP.

[6] Hutchinson, T., and Waters (1987). A. English for Specific Purposes: A Learning-Cent Approach. Cambridge: CUP

[7] KBBI (Kamus Besar Bahasa Indonesia). (2007). Poster. Jakarta: Depdiknas.

[8] Moiinvaziri, Marjan. (2014). Students'Voice : A Need Analysis of University General English Course in Iran.Gema Online. Journal Language Studies. Vol 1(1). 57-75

[9] Richards, J.C. (2001). Curriculum Development in Language Teaching.Cambridge: Cambridge University Press.

[10] Riduwan. (2011). Belajar Mudah Penelitian untuk Guru, Karyawan, dan Peneliti Pemula. Bandung. Alfabeta

[11] Susiana, Rain Kepi Riana. (2009). Media Pembelajaran. Bandung: Wacana Prima

[12] Yunita, W., Emzir \& Mayuni, I. (2018). Need Analysis for English Grammar Learning Model From Students' Perspectives. English Review: Journal of English Education, 6 (2), 85-94. 